\title{
Can Urban Trees Reduce the Impact of Climate Change on Storm Runoff?
}

\author{
Katarina Zabret \\ Mojca Šraj
}

\begin{abstract}
Katarina Zabret, University of Ljubljana, Faculty of Civil and Geodetic Engineering, Department of Environmental Civil Engineering, Slovenia (katarina.zabret@fgg.uni-lj.si)

Mojca Šraj, University of Ljubljana, Faculty of Civil and Geodetic Engineering, Department of Environmental Civil Engineering, Slovenia (mojca.sraj@fgg.uni-lj.si)
\end{abstract}

\begin{abstract}
The process of urbanisation leads to significant changes in surface cover, which influence the hydrological properties of an area. The infiltration of precipitation into the soil is reduced, so that both surface water runoff and the velocity at which water travels have increased drastically. In recent decades climate change has also been observed to affect precipitation trends. Many studies have shown that the amount of rainfall is increasing and that heavy rainfall events are becoming more frequent. These changes are producing more runoff, which has to be drained. Urban trees can reduce the amount of precipitation reaching the ground due to rainfall interception, and are becoming increasingly recognized as an effective means for the regulation of storm water volumes and costs. The study measured rainfall interception in an urban area. It shows that Betula pendula can intercept $20.6 \%$ of annual rainfall, whereas Pinus nigra could intercept as much as $51.0 \%$ of annual rainfall. The advantage of rainfall interception was shown in the case of a parking lot where the planting of trees was able to reduce runoff by up to $17 \%$.
\end{abstract}

Keywords: rainfall interception, green infrastructure, climate change, storm water runoff, Betula pendula, Pinus nigra

\section{Introduction}

Urbanization describes a population shift from rural to urban areas and leads to the formation and growth of cities. It influences various disciplines such as geography, sociology, economics, urban planning, and public health (Internet 1). Urbanisation also changes the hydrological properties of the area.

The properties of an area that influence hydrology are the slope of the terrain, land use, and the presence of vegetation. Urbanisation changes all of these properties. It converts natural watersheds into urban land uses in which the stream hydrology is completely changed as vegetation is removed, stream channels are modified, often channelled or even completely closed, terrain is altered, and the ground sealed with concrete and asphalt, which decreases infiltration and shifts subsurface flow to surface flow (Konrad \& Booth, 2002; Farahmand et al., 2007). Due to different surface conditions in cities, a flashier hydrograph has been observed, with faster onset and decay of storm flows, and higher and earlier peak discharges (Sun et al., 2011).

Surface runoff in cities is already higher and faster than in natural watersheds. In recent decades an even greater increase due to climate change has also been observed. Studies in general indicate an increase in the number of heavy rainfall events (Groisman et al., 2005; Westra et al., 2013; Madsen et al., 2014), changes in river discharges (Sato et al., 2013), and in the frequency of flood events and economic losses (Kron, 2005; Kobold, 2011; IPCC, 2014; Wobus et al., 2014; Bezak et al., 2014). Analyses of precipitation trends shows that in mid-latitude areas very heavy rainfall events are becoming more frequent (Groisman et al., 2005). IPCC (2014) reports a decrease in annual precipitation over the equator and an 
increase over North and South America. The total annual precipitation has not changed significantly in Slovenia but precipitation has increased in autumn and decreased in the winter, spring and summer months (ARSO, 2006; Bezak et al., 2014). Similarly in southern Italy, total annual precipitation has decreased, but the seasonal trend for the summer is positive (Longobardi \& Villani, 2009). The concentration of a large proportion of rainfall in a relatively short period increases storm water runoff and in extreme cases also the occurrence of flood events. Between 1970 and 2012, there were 1,352 reported natural disasters in the world of which $38 \%$ were caused by floods. In this period, floods also caused the highest economic losses, producing $40 \%$ of total damage. The biggest losses were recorded in 2002 flood in Austria, the Czech Republic, and Germany. The estimated damage in Germany was \$14.8 billion (World Meteorological Organisation, 2014).

One of the measures to help cities adapt to climate change is green infrastructure. Green infrastructure is quite quick to implement, inexpensive, and accepted by the public (Matthews et al., 2015). Green infrastructure usually refers to an interconnected network of green areas with multiple functions planned to provide a range of social, ecological and economic benefits (Bendict \& McMahon, 2006; Wright, 2011). The term green infrastructure covers public parks, green avenues and streets, green roofs, urban wetlands, community gardens, permeable vegetated surfaces, and urban forests (Gill et al., 2007; Byrne \& Yang, 2009; Klemm et al., 2015).

The importance of trees in urban areas has recently become better recognized. Due to spreading urbanisation, the impact of trees is becoming increasingly important. As long ago as the early 1990s, Dwyer et al. (1992) reported various benefits of urban trees on the physical and biological environment, such as energy and carbon dioxide conservation, air quality, urban hydrology, noise reduction, and ecological benefits. Among the most important benefits of urban trees are the aesthetic benefits: they are what people see and most often think about. It has been shown that trees can improve residential property values, attract more visitors to recreational areas, and even help people to recover faster from surgery if trees are visible from the hospital bed (Price, 2003). A recent study by Shackleton et al. (2015) presents the benefits of urban trees in South Africa, where the role of trees in maintaining the natural balance in a context of rapid urbanisation, unplanned settlement, and poor service delivery is even more important.

A very important benefit of urban trees is storm water reduction. Due to heavily reduced infiltration in cities, little storage capacity for rainfall remains, so interception by tree canopies is becoming more important. Many studies have shown that significant amounts of rainwater can be held and evaporated from tree canopies (Guevara-Escobar et al., 2007; Šraj et al., 2008b), reducing and delaying the response of an area to rainfall events. Asadian and Weiler (2009) measured rainfall interception by two deciduous tree species in British Columbia, Canada and showed that urban trees can on average intercept 50-60\% of rainfall. Similarly, Guevara-Escobar et al. (2007), who measured interception by isolated trees in Queretaro City, Mexico, calculated a 59.5\% rate of rainfall interception. Armson et al. (2013) measured runoff from three different plots and demonstrated that trees can reduce the runoff coefficient from asphalt surfaces by $38 \%$ in summer and $43 \%$ in winter. Urban forests comprising trees in residential yards were calculated to reduce runoff by 9-21\% (Inkiläinen et al., 2013).

Although trees have an important role in regulating urbanised hydrology systems, there is still little known about the best trees to choose, the right methods of planting, planting costs, and, finally, the benefits to be obtained (Dwyer et al., 1992). A few methods for estimating the costs and benefits of urban trees are available, but if the reduction of runoff by rainfall interception is to be estimated, it has to be measured and studied. The aims of the present study are (1) to evaluate the effect of rainfall interception on storm water runoff by trees with 
different properties, (2) to show the important role of green infrastructure in adaptation to climate change, and (3) to evaluate the costs and benefits of planting trees in urban areas.

\section{Rainfall interception}

Rainfall interception is a process that occurs when precipitation falls above ground covered with vegetation. All types of vegetation intercept rainfall by similar mechanisms but in this paper we have focused on trees, especially in urban areas. When rainfall reaches the tree canopy, some raindrops fall through the gaps between leaves and branches while others are retained in the canopy. Drops retained in the canopy can later reach the ground by dripping. The precipitation that reaches the ground by dripping or falling directly through the gaps is known as throughfall (Figure 1). Another component of precipitation reaching the ground is stemflow, which is the portion of intercepted precipitation that flows down the branches and stem (Figure 1). In the case of deciduous trees, stemflow can even reach up to $20 \%$ of rainfall, while for coniferous trees it is much lower and therefore often neglected (Šraj, 2003; Vilhar et al., 2012). The rest of precipitation never reaches the ground and is intercepted by branches and leaves and retained in the canopy. This is known as intercepted precipitation, which eventually evaporates back into the atmosphere.

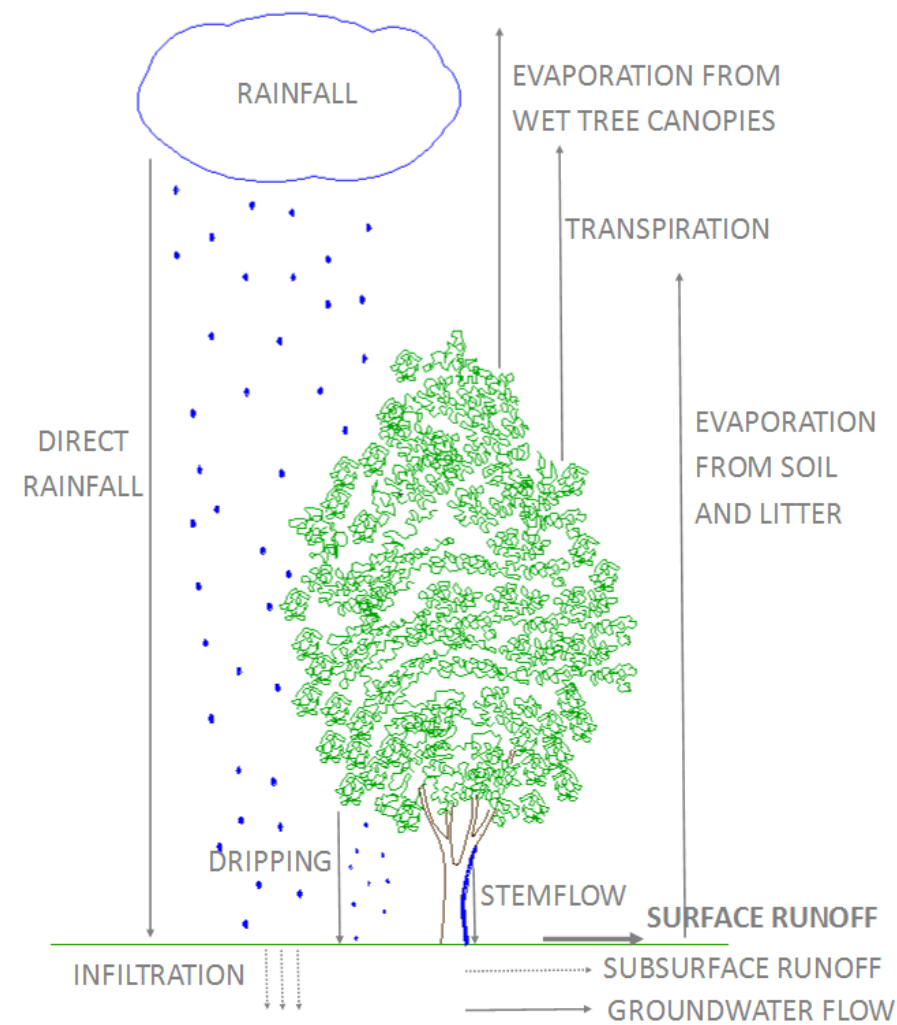

Figure 1: Hydrological cycle showing the rainfall interception process (source: Zabret, 2013).

The majority of rainfall interception studies have been conducted in forests. It has been shown that coniferous trees can intercept between $20 \%$ and $40 \%$, whereas deciduous trees intercept between $20 \%$ and $25 \%$ of rainfall (Geiger et al., 1995). Llorens and Domingo (2007) review studies dealing with rainfall interception in a Mediterranean climate. They have shown that in this area throughfall varies between $26 \%$ and $90 \%$ and stemflow between $0.3 \%$ and $12 \%$.

The amount of precipitation lost by interception depends on various parameters. In general they can be divided into vegetation and meteorological parameters (Crockford \& Richardson, 2000). Vegetation parameters are specific for each tree species, and meteorological parameters depend on the climatic conditions of the research area. The influence of these 
parameters on runoff reduction can be taken into consideration in choosing the appropriate tree species for planting. In cities trees can be planted for various reasons but in any case their additional value in runoff reduction should be taken into account.

\section{Influence of vegetation parameters on rainfall interception}

Vegetation parameters that influence rainfall interception are concerned with the properties of trees. They can significantly influence the amount of precipitation, retained it in the canopy and therefore reducing runoff. The vegetation parameters usually studied or taken into account are canopy storage capacity, leaf area index, tree crown size, diameter at breast height, tree height, bark type and thickness, leaf properties such as inclination, hydrophobicity and wettability, and presence and storage capacity of epiphytes (Zabret, 2013).

Canopy storage capacity is the amount of water stored in the canopy after dripping ceases, and does not equal the total amount of rainfall intercepted (Klaassen et al., 1998). Its value differs depending on vegetation type and period. For deciduous trees, maximum and minimum storage capacity is defined in terms of vegetation period. The leaf area index is defined as the one-sided green leaf area per unit ground surface area $\left[\mathrm{m}^{2} / \mathrm{m}^{2}\right]$ (Šraj, 2003; Fleischbein et al., 2005). It describes the amount of all leaf surfaces in the canopy. Its value is very diverse as it depends on the type of tree, its age and the season in which measurements are taken (Šraj, 2003). Tree crown size is closely connected with diameter at breast height as in the process of rainfall interception they both influence the amount of stemflow. Diameter at breast height is the most common parameter to describe tree age and size. It is measured at $1.30 \mathrm{~m}$ height above the ground (Zabret, 2013). Tree height is not directly connected with the rainfall interception process but, like diameter at breast height, it defines the age and size of the tree. Bark properties mainly influence stemflow. In general, coniferous trees have thicker, rougher and more absorptive bark than deciduous trees, and therefore produce less stemflow. The amount of stemflow also depends on the amount and type of ephipites on the tree trunk and branches (Pypker et al., 2006). Because stemflow is quite small in comparison to total throughfall, the influence of ephipites is taken into account only when they have densely overgrown the trunk or when the main topic of research is stemflow (Nadkarni et al., 2004). How many intercepted rain drops are retained in the canopy and how many form throughfall also depends on the properties of leaves. Hydrophobicity is a measure of the bouncing mechanism for rain drops from a leaf's surface, its inclination determines whether the drop will drip off, and wettability determines the leaf's ability to retain water drops (Holder, 2012; Holder, 2013).

Vegetation parameters generally differ from one tree species to another; the main differences are to be seen between deciduous and coniferous trees. But unlike in forests where trees grow in closed groups, trees in the cities usually grow in isolation, which also influences their properties. For example, urban trees have larger canopies with a larger storage capacity than trees in forests (Xiao and McPherson, 2002).

\section{Influence of meteorological parameters on rainfall interception}

Meteorological parameters in general depend on geographical location and climate type, but can also change during or between single rainfall events. The most important meteorological parameters influencing rainfall interception are the amount of rainfall, rainfall rate and duration, wind velocity and direction, air temperature, humidity, rainfall type, and drop size distribution (Calder, 1996; Crockford \& Richardson, 2000; Nanko et al., 2006; Šraj et al., 2008a). Some are primarily defined by climate type, for example annual amount of precipitation, type of precipitation events (monsoon rain, storms or light showers), and humidity. 
In rainfall interception analysis, single rainfall events are taken into account. Rainfall events are defined as events separated by a period without rain in which canopies can dry out. The length of the drying period between two events is usually chosen on the basis of field observation for each individual event, whereas some values are also recommended in studies (Hamilton \& Rowe, 1949; Steinbuck, 2002). For the purposes of this study in Ljubljana, Slovenia, at least 3 hours drying period was chosen, which was extended in the case of autumn and winter events with low temperatures and fog or after very long rainfall events.

The amount of rainfall is the total rainfall measured that falls during the defined rainfall event. The total amount of rainfall can significantly influence the percentage of rainfall intercepted. In the case of light showers with an amount of rainfall smaller than the canopy storage capacity, trees can intercept up to $100 \%$ of rainfall. Rainfall duration is usually measured by rain gauges equipped with automatic data loggers, which record both the amount of rainfall and time. Rainfall rate is calculated as the ratio between rainfall amount and duration, and is usually expressed in millimeters per hour. In general, a higher rainfall rate decreases rainfall interception (Xiao et al., 2000; Guevara-Ecsboar et al., 2007). The deffinition of rainfall types is quite subjective, as meteorological classification as well as classification based on observations can be used. Nanko et al. (2006) divide events into three types (calm, heavy rain, and strong wind) based on observations. The influence of drop size distribution on amount of interception is not yet well quantified.

Wind velocity not only drifts rain drops but also shakes the tree canopy and therefore induces higher throughfall (Šraj, 2008a). Wind direction in cities is closely connected with the location of buildings, which can form a slipstream near the tree, preventing the shaking of the canopy; or a wind canyon can be formed between buildings, causing even higher wind speeds than in a natural area (Blocken \& Carmeliet, 2004). Air temperature and humidity are more important after the rainfall event, as, in addition to wind velocity and solar radiation, they have quite a significant impact on evapotranspiration. The earlier evapotranspiration starts, the fewer drops fall to the ground. In general, higher temperatures cause higher evaporation rates, whereas higher humidity brings less evaporation. This is very important in the cities where the temperature is higher due to urban heat-islands, and with increasing evaporation due to edge effects, rainfall interception is influenced differently than in forests (GuevaraEscobar et al., 2007).

\section{Methods}

The analysis of the influence of urban trees in reducing the impact of climate change on storm water runoff in the present study comprises four steps. Precipitation today was measured and precipitation in 2100 was estimated, taking climate change into account. Throughfall and stemflow were measured for different types of trees on the experimental plot in Ljubljana and their interception efficiency was calculated. All the data collected were then used to estimate the reduction of storm water by trees, taking the example of a parking lot in Ljubljana. The costs and benefits of such measures were evaluated.

\section{Site description}

The study plot is located in the city of Ljubljana, Slovenia $\left(46.04^{\circ} \mathrm{N}, 14.49^{\circ} \mathrm{E}\right)$ at $292 \mathrm{~m}$ asl. The climate is continental, category $\mathrm{CfB}$ under the Köppen climate classification system. The average annual temperature is $11^{\circ} \mathrm{C}$, ranging from $-5^{\circ} \mathrm{C}$ to $28^{\circ} \mathrm{C}$. The long term average annual rainfall is $1342 \mathrm{~mm}$ (ARSO, 2006).

Rainfall interception was measured in an urban area of Ljubljana city (Figure 2). The study plot covers approximately $600 \mathrm{~m}^{2}$ and consists of two groups of trees and a clearing. Measurements of throughfall and stemflow were taken under four trees, two Pinus nigra (black pine) and two Betula pendula (birch). Throughfall was measured by three different 
methods under each type of tree: steel trough gauge $(2.5 \times 0.3 \mathrm{~m})$ equipped with a tipping bucket flow gauge (Unidata 6506G) and an automatic data logger (Onset HOBO Event), identical trough gauges with manually collected polyethylene 101 containers also connected with a 501 polyethylene barrel and ten roving manually-read wedge gauges with 11 capacity and $78.5 \mathrm{~cm}^{2}$ catch area. Total precipitation was also measured with a tipping bucket $(0.2$ $\mathrm{mm} /$ tip) rain gauge (Onset RG2-M) with automatic data logger (Onset HOBO Event) on the clearing at the study plot.

The reduction of storm water runoff by urban trees was estimated for a parking lot "Dolgi most" near the study plot (Figure 2). The parking lot had just recently been rebuilt (summer 2015), however in analysis we have taken into account the situation before reconstruction. The area of the parking lot is $12,677 \mathrm{~m}^{2}$ and has 200 parking spaces with a total area of 1,600 $\mathrm{m}^{2}$ and $1,368 \mathrm{~m}^{2}$ of green surfaces covered by grass.

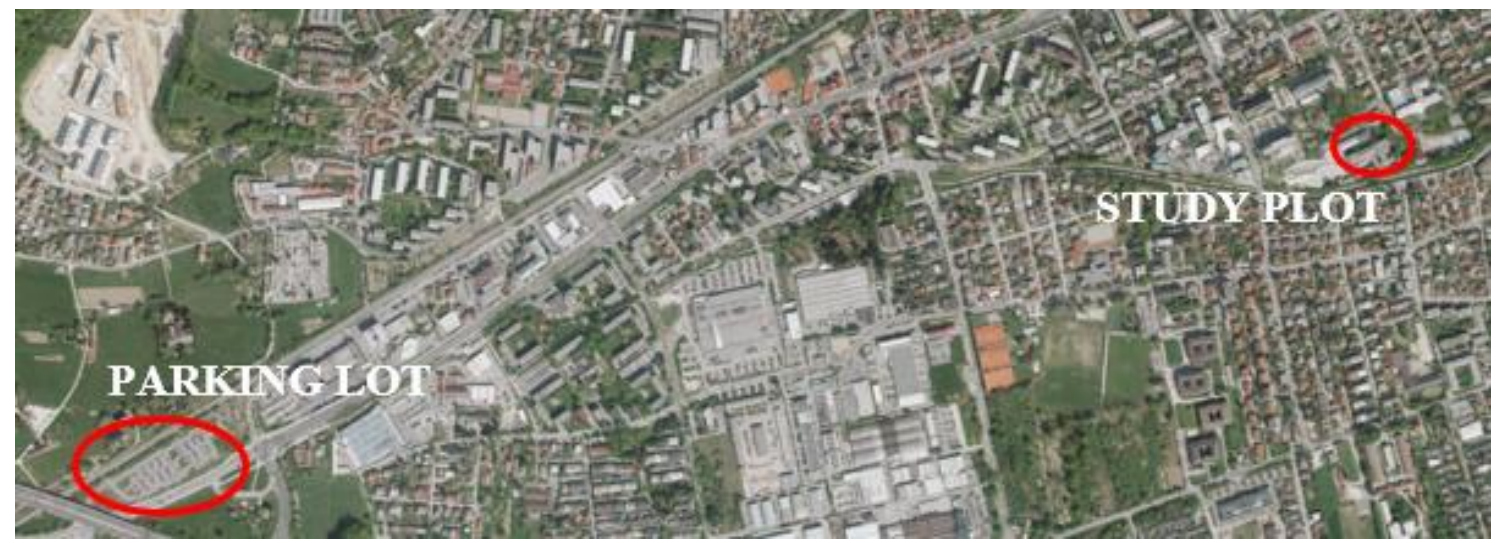

Figure 2: Locations of parking lot and study plot (source: Geopedia, 2015).

\section{Estimation of the costs of storm water runoff reduction}

In 2004, the Centre for Neighborhood Technology in the USA developed an online calculator for quick comparison of the performance, costs, and benefits of green infrastructure with conventional storm water practices, called the Green Values Stormwater Management Calculator (CNT, 2015). It is a first step towards understanding the role of green areas in the urban environment. Basically the program has been developed for use in the United States of America but can also be used elsewhere.

The design of the software is quite simple. The instructions guide the user in entering the data step by step. The data required are annual precipitation, total size of the studied area and the dimensions of all other elements of the area (roofs, sidewalks, parking spots), initial land cover data, and type of green improvements. Some advanced options for calculating expenses and savings are also available.

\section{Estimation of precipitation scenarios}

To calculate storm water reduction with the Green Values Stormwater Management Calculator, data on annual precipitation are necessary. To evaluate the impact of climate change, we used data on measured precipitation in 2014 and on forecasted precipitation in 2100. Annual precipitation in 2014 was $1672.1 \mathrm{~mm}$ as measured during research. Snow was not taken into account as it does not produce instant runoff. The precipitation forecast was obtained from the study by Rakovec and Ceglar (2012). The data were extracted from the grid data base of the European observation system (E-OBS). The E-OBS dataset was defined on the 0.25 degree grid resolution and the data collected between 1961 and 2010 were used in the study. For the city of Ljubljana in 2100 they estimated that the amount of precipitation in spring would largely remain unchanged, dropping in summer by $20 \%$ while rising in autumn 
and winter by $30 \%$ and $40 \%$, respectively. Taking these values into account we estimated that annual rainfall in Ljubljana city in 2100 would be $10 \%$ higher.

\section{A scenario for planting trees}

The parking lot measures $12,677 \mathrm{~m}^{2}$ with 200 parking spaces. $89 \%$ of the surface is impermeable and $11 \%$ is permeable grass areas. The grass was estimated to have an average coverage on a flat terrain. According to Chow et al. (1988), the coefficient of runoff from such a surface is $30 \%$. The impermeable surfaces on the parking lot can be reduced by planting trees. There are many scenarios for doing this. We decided to plant 200 trees and thus reduce the area of impermeable surfaces by $4,000 \mathrm{~m}^{2}$ (Figure 3 ). The majority of trees were to be planted between the rows of parking spaces. This would provide additional benefits, i.e. shade for cars, much appreciated by drivers especially in summer (Centre for Urban Forest Research, 2002).

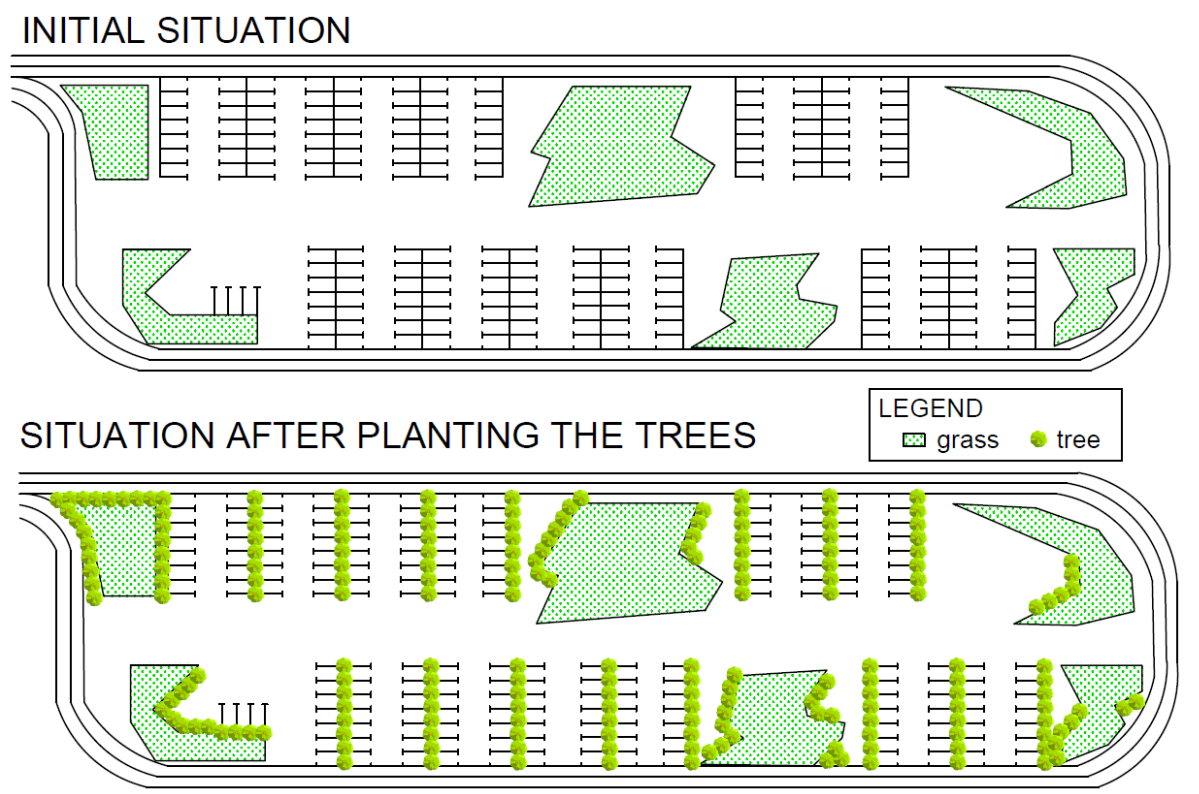

Figure 3: The situation of a parking lot before and after planting the trees.

\section{Results and discussion \\ Rainfall interception}

The amount of rainfall intercepted causing a reduction in runoff was measured over one year in Ljubljana under two different types of trees (B. pendula and P. nigra). In year 2014 a total of 176 rainfall events occurred and delivered $1672.1 \mathrm{~mm}$ of gross precipitation to the study area. Throughfall under $B$. pendula varied between $0 \%$ and $100 \%$ per event. It was registered in 132 events and amounted to $1260.8 \mathrm{~mm}$ or $75.4 \%$ of gross precipitation. Under P. nigra the highest throughfall detected in individual events amounted to $93 \%$ of gross precipitation. Overall, 125 throughfall events were registered, accounting in total for $818.8 \mathrm{~mm}$ or $49.0 \%$ of gross precipitation (Figure 4). Throughfall values are highly dependent on leafed and leafless periods typical for deciduous trees. For example, in the leafless period throughfall under $B$. pendula was almost $23 \%$ higher than in the leafed period. Stemflow was much lower and occurred less often than throughfall. In the case of B. pendula, a total of $67.1 \mathrm{~mm}$ or $4 \%$ of gross annual precipitation was measured whereas stemflow on P. nigra amounted to only 1.1 $\mathrm{mm}$ or $0.7 \%$ of gross precipitation (Figure 4). Stemflow values depend strongly on bark 
properties. $P$. nigra bark is rougher and thicker than $B$. pendula, which is one of the reasons for the difference in stemflow. It was so low in case of $P$. nigra as to be negligible.

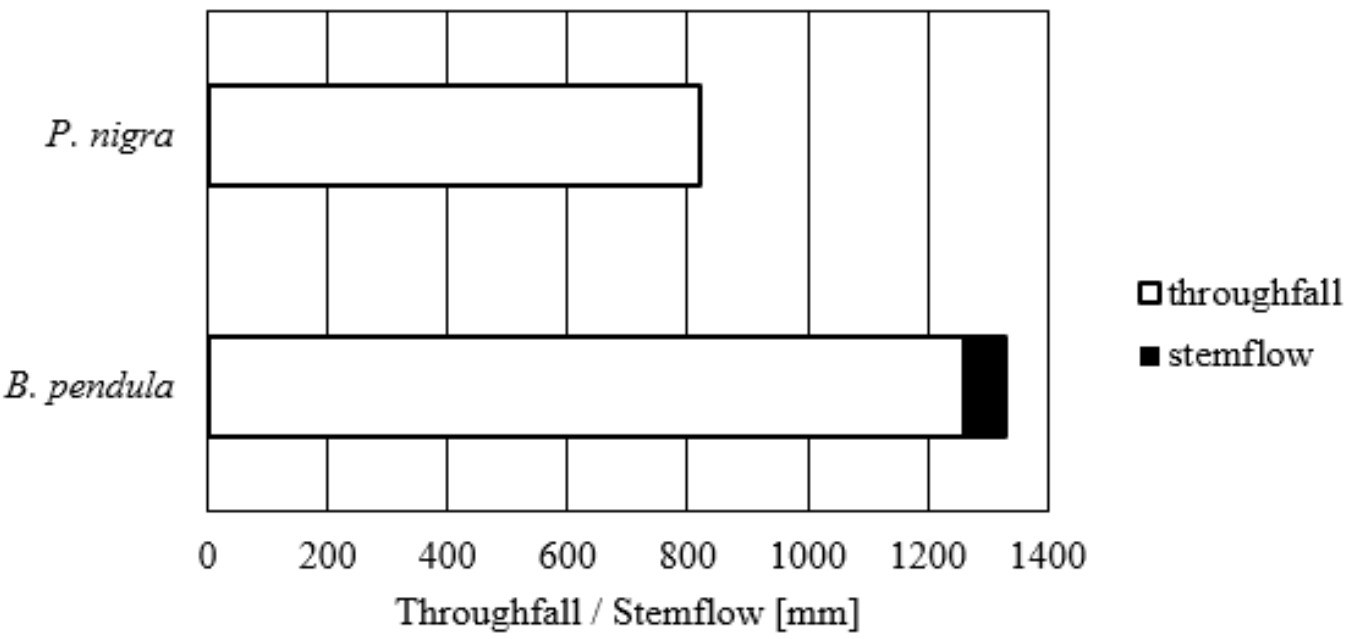

Figure 4: Throughfall and stemflow for B. pendula and P. nigra.

Rainfall interception is equal to the difference between gross precipitation and precipitation reaching the ground (sum of throughfall and stemflow). Therefore interception losses totalled $20.6 \%$ of yearly gross precipitation under B. pendula and $51.0 \%$ of yearly gross precipitation under $P$. nigra. The results are similar to those of previous studies. Asadian and Weiler (2009) observed rainfall interception by coniferous trees in urban areas at a level of $50 \%$ for Pseudotsuga menziesii and 54\% for Thuja plicata. Rainfall interception by B. pendula of between $15 \%$ and $27 \%$ of gross precipitation was also measured in urban areas for Pyrus calleryana and Quercus suber, respectively (Xiao et al., 2000). Interception values per event ranged from $0 \%$ to $100 \%$ and were on average highest for $P$. nigra in summer time (Figure 5). In general $P$. nigra intercepted more rainfall than $B$. pendula regardless of the time of year. The difference was highest in the leafless period during the winter. In spring and autumn rainfall events are more intensive and last longer, so that quite a strong difference in interception by $B$. pendula and P. nigra can also be observed, although part of these seasons fall in the leafless period and part in the leafed period.

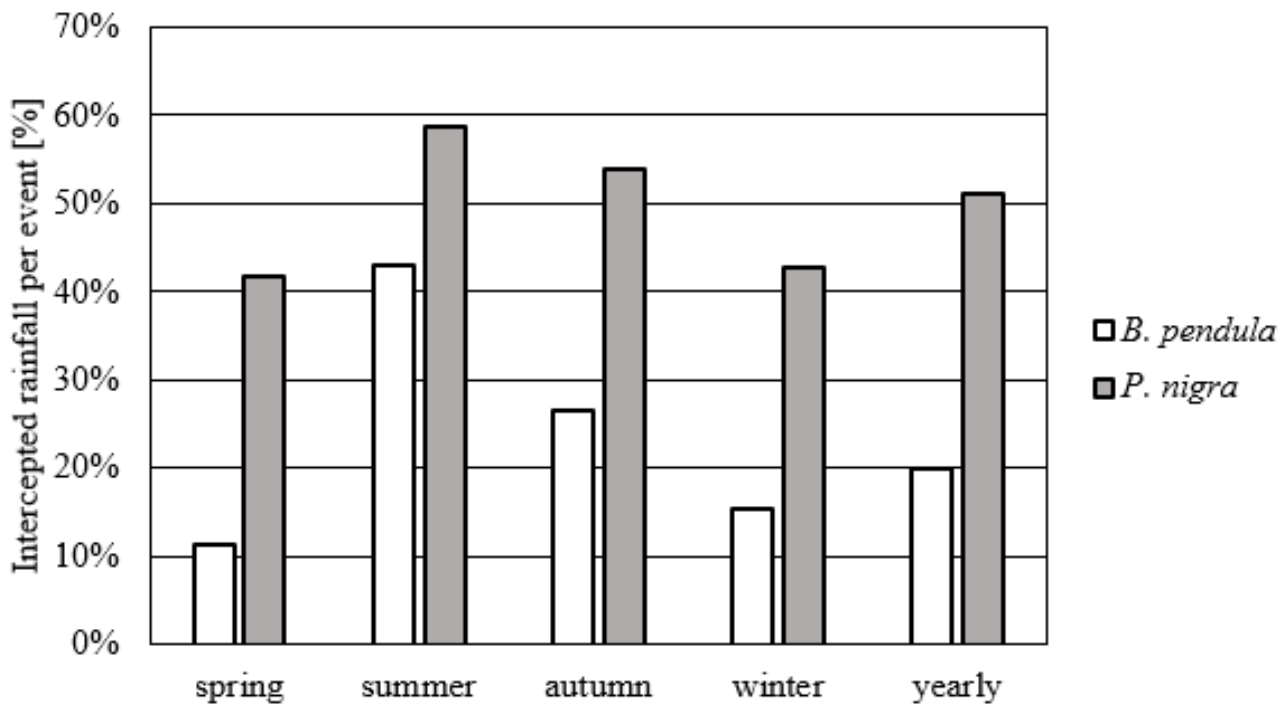

Figure 5: Average interception losses per event by B. pendula and P. nigra by season. 
The measurements have shown the influence of vegetation and meteorological parameters on the amount of rainfall interception. In general, coniferous trees intercept more rainfall than deciduous trees and are therefore more affective in runoff reduction. If the majority of rainfall is expected in spring or summer, deciduous trees can also be taken into account, whereas in areas with very wet autumn and winter periods and dry spring and summer periods it makes little sense to plant these tree species for purposes of runoff reduction. In addition to the effectiveness of trees for runoff reduction, there are other issues to be considered (Appleton et al., 2009). For example, deciduous trees lose leaves, which accumulate on cars and on the parking lot, causing slippery road surfaces and therefore requiring regular cleaning in autumn. Coniferous trees usually have denser canopies with lower branches that can obstruct parking cars and reduce the effective parking area. Therefore, regular branch cutting and canopy maintenance are required. Trees can also cause problems with roots, which can damage the asphalt.

\section{Runoff reduction}

Runoff was calculated as the sum of runoffs from each land use type of the parking lot. In $201419,565 \mathrm{~m}^{3}$ of runoff from the parking lot was calculated for the annual amount of rainfall. The total amount is already somewhat reduced by the grass surfaces, which retain $7.7 \%$ of annual rainfall. If 200 trees were planted, this would reduce asphalt surfaces by $35.5 \%$. If the trees planted were $B$. pendula, runoff reduction would be $7 \%$, whereas in the case of $P$. nigra runoff reduction would be $17 \%$ (Table 1). Estimation of the effect of climate change on precipitation shows that in 2100 there would be $10 \%$ more rainfall per year than today (Table 1). This would cause $21,521 \mathrm{~m}^{3}$ of runoff from the parking lot without trees. $B$. pendula and $P$. nigra would reduce runoff to a similar degree but the reduction in runoff and consequently reduced costs of storm water management would be higher.

Table 1: Reduction of runoff due to planting of 200 trees

\begin{tabular}{lll}
\hline Situation & $\begin{array}{l}\text { Runoff in } \\
\text { year 2014 }\left[\mathbf{m}^{3}\right]\end{array}$ & $\begin{array}{l}\text { Runoff in } \\
\text { year 2100 }\left[\mathbf{m}^{3}\right]\end{array}$ \\
\hline Without trees & 19,565 & 21,521 \\
B. pendula & 18,187 & 20,007 \\
P. nigra & 16,154 & 17,769 \\
\hline
\end{tabular}

\section{Cost and benefits estimation}

The costs and benefits of planting trees were estimated by means of the Green Values Stormwater Management Calculator. In the study we have taken into account the planting of 200 trees with an average canopy area of $20 \mathrm{~m}^{2}$ and a 50 year lifecycle. Other information used in the study are the area of impermeable and permeable (lawn in fair condition) surfaces, precipitation data, and data on tree box size. The estimation of costs covers equipping the parking lot with a system for storm water storage, laying turf and, in case of planting trees, the cost of trees, material for tree boxes and additional soil. Construction of a conventional parking lot as in the initial situation (Figure 3) would in total cost almost $€ 700,000$ whereas building a parking lot with trees would cost nearly $€ 890,000$ or almost $30 \%$ more (Table 2 ). The biggest additional cost item for tree planting is material for tree boxes. Construction of the parking lot and storm water storage system alone is $33 \%$ cheaper in the case of a parking lot with trees than without them. 
Table 2: Cost of building of parking lot without and with trees

\begin{tabular}{llll}
\hline Costs & $\begin{array}{l}\text { Conventional } \\
\text { parking lot }\end{array}$ & $\begin{array}{l}\text { Parking lot } \\
\text { with trees }\end{array}$ & Difference \\
\hline Parking Lot & $600,486 €$ & $387,783 €$ & $-35 \%$ \\
Storm water Storage & $94,249 €$ & $76,103 €$ & $-19 \%$ \\
Turf & $2,818 €$ & $2,818 €$ & $0 \%$ \\
Trees & & $49,376 €$ & $0 \%$ \\
Tree Box Filters & & $249,372 €$ & $0 \%$ \\
Additional Soil & & $123,440 €$ & $0 \%$ \\
Total & $697,553 €$ & $888,892 €$ & $27 \%$ \\
\hline
\end{tabular}

According to McPherson et al. (2005), community spending on storm water management amounts to $\$ 0.005 /$ gal or $€ 0.0012 / 1$ or $€ 1.2 / \mathrm{m}^{3}$. Currently the costs of storm water management for a plain parking lot are $€ 23,478$ per year and can be reduced by $€ 4,000$ per year by planting trees. By 2100, the costs without any measures being taken would rise to $€$ 25,826 per year. By planting trees, costs could be held even below the current level, as the estimated price of runoff management for the planted parking lot in year 2100 being $€ 21,323$. The benefits of planting trees extend beyond storm water runoff reduction to various other improvements and cost reductions. Trees can also reduce air pollution and carbon dioxide concentrations, contribute to groundwater replenishment, reduce energy use, help to control noise; they have recreational and landscape design benefits and also influence public health, increase property values, and have other positive ecological, sociological and physicals benefits (Dwyer et al., 1992; Price, 2003; Tyrvainen et al., 2005; Soares et al., 2011; Shackleton et al., 2015). Since trees in urban areas bring so many benefits, their total value is hard to calculate. The Green Values Stormwater Management Calculator was therefore used to calculate only a few of the easiest items to estimate. The results show that in one year trees would provide benefits worth almost $€ 55,000$, which is already more than quarter of the cost of planting the trees. If the life cycle of the trees is 50 years, the benefits over this period would be more than $€ 1.5$ million. The greatest benefit is the compensatory value (Table 3 ). It is widely acknowledged that a home or commercial area near green space or water has a higher value than they would without such amenities. This increased value is usually measured in terms of sale or rental price and the compensatory value is often used in the insurance industry to estimate the cost of replacing a tree (Watson, 2002).

Table 3: Benefits of building a parking lot with trees

\begin{tabular}{lll}
\hline Benefits & One year & 50 years \\
\hline Reduced Air Pollutants & $€ 32.3$ & $€ 947.1$ \\
Carbon Dioxide Sequestration & $€ 21.5$ & $€ 628.4$ \\
Compensatory Value of Trees & $€ 49,376.1$ & $€ 1,439,198.3$ \\
Groundwater Replenishment & $€ 14.4$ & $€ 421.0$ \\
Storm water runoff reduction & $€ 4,093.3$ & $€ 214,897.6$ \\
Total & $€ 53,537.6$ & $€ 1,656,092.5$ \\
\hline
\end{tabular}

\section{Conclusions}

The green infrastructure in urban areas is becoming increasingly important. It not only reduces the changes and mitigates the alterations caused by urbanization but also helps adapt to climate change. The green infrastructure includes urban trees, which can be planted in parks, private gardens, parking lots and along streets. Urban trees provide many positive impacts. With the reduction of storm water runoff they also help to reduce the impact of climate change. 
The amount of rainfall intercepted and therefore the amount of runoff reduction depends on tree properties which have to be considered before planting. In 2014 B. pendula intercepted $20.6 \%$ and $P$. nigra $51 \%$ of total rainfall. $P$. nigra is a coniferous tree, evergreen with a dense canopy, negative branch inclination and rough and thick bark. It intercepted more rainfall than B. pendula. This deciduous tree has leafed and leafless periods, smoother and thinner bark, and positive branch inclination, which intercepts $30 \%$ less rainfall than $P$. nigra. The study has shown that precipitation interception is influenced by tree properties, but not all were looked at. Evaluation of the parameters' impact on rainfall interception is quite complex and taking more parameters into account can provide intransparent results. Researchers therefore usually focus on a limited number of parameters at a time (Fleischbein et al., 2005; GuevaraEscobar et al., 2007; Asadian \& Weiler, 2009; Siegert et al., 2016). To be able to cover all of these parameters as realistically as possible, more studies should be undertaken for various tree species.

The reduction of storm water runoff due to the rainfall interception will become increasingly important. Due to climate change, a higher annual amount of precipitation is expected in fewer events. Intensive rainfall events cause quick runoff response in urban areas which can be regulated and lowered by urban trees. The runoff on the parking lot under study could be reduced by almost $18 \%$ through a $35 \%$ reduction in the impermeable surface due to tree planting. The costs of such alterations are $30 \%$ higher in our case but various other benefits and costs reductions brought by trees can cover this cost in only 4 years.

The reduction of runoff due to the rainfall interception should be measured for other tree species, too. The results would give more information about the influence of other parameters on runoff reduction and importance of urban trees.

\section{References}

Appleton, B., Horsley, J., Harris, V., Eaton, G., Fox, L. \& Orband, J. (2009) Trees for parking lots and paved areas. Available at: https://pubs.ext.vt.edu/430/430-028/430-028.html (accessed 10 Sept. 2015)

Armson, D., Stringer, P. \& Ennos, A.R. (2013) The effect of street trees and amenity grass on urban surface water runoff in Manchester, UK. Urban Forestry \& Urban Greening, 12, pp. 282-286. DOI: http://dx.doi.org/10.1016/j.ufug.2013.04.001

ARSO (2006) Podnebne razmere v Sloveniji (The climatic conditions in Slovenia). Available at: http://www.arso.gov.si/vreme/podnebje/podnebne_razmere_Slo71_00.pdf (accessed 7 May 2015).

Asadian, Y. \& Weiler, M. (2009) A new approach in measuring rainfall interception by urban trees in coastal British Columbia. Water Quality Research Journal of Canada, 44, pp. $16-25$.

Bendict, M.A., \& McMahon, E.T. (2006) Green infrastructure: Linking landscapes and communities. Washington, Island Press.

Bezak, N., Brilly, M. \& Sraj, M. (2014) Flood frequency analyses, statistical trends and seasonality analyses of discharge data: a case study of the Litija station on the Sava River. Journal of Flood Risk Management. DOI: 10.1111/jfr3.12118.

Blocken, B. \& Carmeliet, J. (2004) Pedestrian wind environment around buildings: literature review and practical examples. Journal of Building Physics, 28, pp. 107-159. DOI: $10.1177 / 1097196304044396$

Byrne, J. \& Yang, J. (2009) Can urban greenspace combat climate change? Towards a subtropical cities research agenda. Australian Planner, 46, pp. 36-43. DOI:

10.1080/07293682.2009.1075342036-43. 
Calder, I.R. (1996) Dependence of rainfall interception on drop size: 1. Development of the two-layer stochastic model. Journal of hydrology, 185, pp. 363-378. DOI: 10.1016/00221694(95)02998-2

Centre for Urban Forest Research (2002) Where are all the cool parking lots? Available at: http://sactree.com/assets/files/greenprint/toolkit/b/CoolParkingLots.pdf. (accessed 2 Sep. 2015)

Chow, V.T., Maidment, D.R. \& Mays, L.W. (1988) Applied hydrology. Singapur, McGrawHill Book Company.

CNT (2015) Green Values Stormwater Toolbox. Available at: http://greenvalues.cnt.org/ (accessed 7 Sep. 2015).

Crockford, R.H. \& Richardson, D.P. (2000) Partitioning of rainfall into throughfall, stemflow and interception: effect of forest type, ground cover and climate. Hydrological Processes, 14, pp. 2903-2920. DOI: 10.1002/1099-1085(200011/12)

Dwyer, J.F., McPherson, E.G., Schroeder, H.W. \& Rowntree, R.A. (1992) Assessing the benefits and costs of the urban forest. Journal of Arboriculture, 18(5), pp. 227-234.

Farahmand, T., Fleming, S.W. \& Quilty, E.J. (2007) Detection and visualization of storm hydrograph changes under urbanization: An impulse response approach. Journal of Environmental Management, 85(1), pp. 93-100. DOI: 10.1016/j.jenvman.2006.08.004

Fleischbein, K., Wilcke, W., Goller, R., Boy, J., Valarezo, C., Zech, W. \& Knoblich, K. (2005) Rainfall interception in a lower montane forest in Ecuador: effects of canopy properties. Hydrological Processes, 19, pp. 1355-1371. DOI: 10.1002/hyp.5562

Geiger, R., Aron, R.H. \& Todhunter, P. (1995) The climate near the ground. Wiesbaden, Friedr. Vieweg \& Sohn.

Geopedia (2015) Available at: http://www.geopedia.si (accessed 7 Sep. 2015)

Gill, S.E., Handley, J.F., Ennos, A.R. \& Pauleit, S. (2007) Adapting cities for climate change: The role of the green infrastructure. Built Environment, 33, pp. 115-133. DOI: http://dx.doi.org/10.2148/benv.33.1.115

Groisman, P.Y., Knight, R.W., Easterling, D.R., Karl, T.R., Hegerl, G.C. \& Razuvaev, V.N. (2005) Trends in intense precipitation in the climate record. Journal of climate, 18, pp. 1362-1350. DOI: http://dx.doi.org/10.1175/JCLI3339.1

Guevara-Escobar, A., Gonzales-Sosa, E., Veliz-Chavez, C., Ventura-Ramos, E. \& RamosSalinas, M. (2007) Rainfall interception and distribution patterns of gross precipitation around an isolated Ficus benjamina tree in an urban area. Journal of Hydrology, 333, pp. 532-541. DOI:10.1016/j.jhydrol.2006.09.017

Hamilton, E.L. \& Rowe, P.B. (1949) Rainfall interception by chaparral in California. Sacramento, Department of Natural Resources, Division of Forestry.

Holder, C.D. (2012) The relationship between leaf hydrophobicity, water droplet retention, and leaf angle of common species in a semi-arid region of the western United States. Agricultural and Forest Meteorology, 152, pp. 11-16. DOI: 10.1016/j.agrformet.2011.08.005

Holder, C.D. (2013) Effects of leaf hydrophobicity and water droplet retention on canopy storage capacity. Ecohydrology, 6, pp. 483-490. DOI: 10.1002/eco.1278

Inkiläinen, N.M., McHale, M.R., Blank, G.B., James, A.L. \& Nikinmaa, E. (2013) The role of the residential urban forest in regulating throughfall: A case study in Raleigh, North Carolina, USA. Landscape and Urban Planning, 119, pp. 91-103. DOI: 10.1016/j.landurbplan.2013.07.002

Internet 1: https://en.wikipedia.org/wiki/Urbanization (accessed 7 Sep. 2015).

IPCC (2014) Summary for policymakers. In: Climate Change 2014: Impacts, Adaptation, and Vulnerability. Part A: Global and Sectoral Aspects. Contribution of Working Group II to the Fifth Assessment Report of the Intergovernmental Panel on Climate Change. 
Available at: http://www.ipcc.ch/pdf/assessment-report/ar5/wg2/ar5_wgII_spm_en.pdf (accessed 25 Avg. 2015)

Klaassen, W., Bosveld, F. \& de Water, E. (1998) Water storage and evaporation as constituents of rainfall interception. Journal of Hydrology, 212-213, pp. 36-50. DOI: 10.1016/S0022-1694(98)00200-5

Klemm, W., Heusinkveld, B.G., Lenzholzer, S. \& Van Hove, B. (2015) Street greenery and its physical and psychological impact on outdoor thermal comfort. Landscape and Urban Planning, 138, pp. 87-98. DOI: 10.1016/j.landurbplan.2015.02.009

Kobold, M. (2011) Comparison of floods in September 2010 with registered historic flood events. Ujma, 25, pp. 48-56.

Konrad, C.P. \& Booth, D.B. (2002) Hydrologic trends associated with urban development for selected streams in the Puget Sound basin, western Washington. Water-Resources Investigations Report 02-4040. Tacoma, Washington, U.S. Geological Survey.

Kron, W. (2005) Flood. In: Berz, G. (ed.) Weather catastrophes and climate change: is there still hope for us?, pp. 122-131. München, Münchener Rückversicherungs-Gesellschaft.

Llorens, P. \& Domingo, F. (2007) Rainfall partitioning by vegetation under Mediterranean conditions. A review of studies in Europe. Journal of Hydrology, 335, pp. 37- 54. DOI: 10.1016/j.jhydrol.2006.10.032

Longobardi, A. \& Villani, P. (2009) Trend analysis of annual and seasonal rainfall time series in the Mediterranean area. International journal of climatology, 30, pp. 1538-1546. DOI: 10.1002/joc. 2001

Madsen, H., Lawrence, D., Lang, M., Martinkova, M. \& Kjeldsen, T.R. (2014) Review of trend analysis and climate change projections of extreme precipitation and floods in Europe. Journal of Hydrology, 519, pp. 3634-3650. DOI: 10.1016/j.jhydrol.2014.11.003

Matthews, T., Lob, A.Y. \& Byrnec J.A. (2015) Reconceptualizing green infrastructure for climate change adaptation: Barriers to adoption and drivers for uptake by spatial planners. Landscape and Urban Planning, 138, pp. 155-163. DOI: 10.1016/j.landurbplan.2015.02.010

McPherson, G., Simpson, J.R., Peper, P.J., Maco, S.E. \& Xiao, Q. (2005) Municipal Forest Benefits and Costs in Five US Cities. Journal of forestry, 103(8), pp. 411-416.

Nadkarni, N.M., Schaefer, D., Matelson, T.J. \& Solano, R. (2004) Biomass and nutrient pools of canopy and terrestrial components in a primary and a secondary montane cloud forest, Costa Rica. Forest Ecology and Management, 198, pp. 223-236. DOI: 10.1016/j.foreco.2004.04.011

Nanko, K., Hotta, N. \& Suzuki, M. (2006) Evaluating the influence of canopy species and meteorological factors on throughfall drop size distribution. Journal of Hydrology, 329, pp. 422-431. DOI:10.1016/j.jhydrol.2006.02.036

Price, C. (2003) Quantifying the aesthetic benefits of urban forestry. Urban Forestry and Urban Greening, 1(3), pp. 123-133. DOI: 10.1078/1618-8667-00013

Pypker, T.G., Unsworth, M.H. \& Bond, B.J. (2006) The role of epiphytes in rainfall interception by forests in the Pacific Northwest. I. Laboratory measurements of water storage. Canadian Journal of Forest Research, 36(4), pp. 809-818. DOI: 10.1139/X05286

Rakovec, J. \& Ceglar, A. (2012) Report on the development of climate projections for Sava river basin. Part I of report for the Sava Commission. Ljubljana, University of Ljubljana.

Sato, Y., Kojiri, T., Michihiro, Y., Suzuki, Y. \& Nakakita, E. (2013) Assessment of climate change impacts on river discharge in Japan using the super-high-resolution MRI-AGCM. Hydrological Processes, 27(3), pp. 3264-3279. DOI: 10.1002/hyp.9828

Shackleton, S., Chinyimbaa, A., Hebinckb, P., Shackletona, C. \& Kaomaa, H. (2015) Multiple benefits and values of trees in urban landscapes in two towns in northern South 
Africa. Landscape and Urban Planning, 136, pp. 76-86. DOI:

10.1016/j.landurbplan.2014.12.004

Siegert, C.M., Levia, D.F., Hudson, S.A., Dowtin, A.L., Zhang, F., Mitchell, M.J. (2016)

Small-scale topographic variability influences tree species distribution and canopy throughfall partitioning in a temperate deciduous forest. Forest Ecology and Management, 359, pp. 109-117. DOI: 10.1016/j.foreco.2015.09.028

Soares, A.L., Rego, F.C., McPherson, E.G., Simpson, J.R., Peper, P.J., Xiao, Q. (2011) Benefits and costs of street trees in Lisbon, Portugal. Urban Forestry and Urban Greening, 10, pp. 69-78. DOI: 10.1016/j.ufug.2010.12.001

Steinbuck, E. (2002) The influence of tree morphology on stemflow in a redwood region second-growth forest. Msc Thesis, Chico, Faculty of California State University.

Sun, Z., Guo, H., Li, X., Huang, Q. \& Zhang, D. (2011) Effect of LULC change on surface runoff in urbanization area. Paper presented at ASPRS 2011 Annual Conference, 1-5 May, Milwaukee, Wisconsin. Typescript.

Šraj, M. (2003) Modeliranje in merjenje prestreženih padavin. Doctoral Thesis, Ljubljana, University of Ljubljana, Faculty of Civil and Geodetic Engineering.

Šraj, M., Brilly, M. \& Mikoš, M. (2008a) Rainfall interception by two deciduous Mediterranean forests of contrasting stature in Slovenia. Agricultural and forest meteorology, 148(1), pp. 121-134. DOI: 10.1016/j.agrformet.2007.09.007

Šraj, M., Lah, A. \& Brilly, M. (2008b) Measurements and Analysis of Intercepted Precipitation of Silver Birch (Betula pendula Roth.) and Scots Pine (Pinus sylvestris L.) in Urban Area. Gozdarski vestnik, 66(9), pp. 406-433.

Tyrvainen, L., Pauleit, S., Seeland, K. \& de Vries, S. (2005) Benefits and uses of urban forests and trees. In: Konijnendijk, C.C., Nilsson, K., Randrup, T.B., Schipperijn, J. (eds.) Urban forests and trees. Berlin, New York, Springer.

Vilhar, U., Kobal, M. \& Simončič, P. (2012) Kroženje vode v bukovih gozdovih. In: Bončina, A. (eds.) Bukovi gozdovi v Sloveniji: ekologija in gospodarjenje, pp. 103-113. Ljubljana, University of Ljubljana, Biotechnical Faculty.

Watson, G. (2002) Comparing formula methods of tree appraisal. Journal of Arboriculture, 28(1), pp. 11-18.

Westra, S., Alexander, L.V. \& Zwiers, F.W. (2013) Global increasing trends in annual maximum daily precipitation. Journal of climate, 26, pp. 3904-3918. DOI: http://dx.doi.org/10.1175/JCLI-D-12-00502.1

Wobus, C., Lawson, M., Jones, R., Smith, J. \& Martinich, J. (2014) Estimating monetary damages from flooding in the United States under a changing climate. Journal of Flood Risk Management, 7, pp. 217-229. DOI: 10.1111/jfr3.12043

World Meteorological Organization (2014) Atlas of mortality and economic losses from weather, climate and water extremes (1970-2012). Available at: http://www.wmo.int/pages/prog/drr/transfer/2014.06.12-WMO1123_Atlas_120614.pdf (accessed 25 Avg. 2015)

Wright, H. (2011) Understanding green infrastructure: The development of a con-tested concept in England. Local Environment, 16 (10), pp. 1003-1019. DOI:10.1080/13549839.2011.631993

Xiao, Q., McPherson, E.G., Ustin, S.L., Grismer, M.E. \& Simpson, J.R. (2000) Winter rainfall interception by two mature open-grown trees in Davis, California. Hydrological processes, 14, pp. 763-784. DOI: 10.1002/(SICI)1099-1085(200003)

Xiao, Q. \& McPherson, G.E. (2002) Rainfall interception by Santa Monica's municipal urban forest. Urban Ecosystems, 6, pp. 291-302. DOI: 10.1023/B:UECO.0000004828.05143.67

Zabret, K. (2013) The influence of tree characteristics on rainfall interception. Acta hydrotechnica, 26, pp. 99-116. 